Article

\title{
A Bottom-Up Approach for Data Mining in Bioaromatization of Beers Using Flow-Modulated Comprehensive Two-Dimensional Gas Chromatography/Mass Spectrometry
}

\author{
Andre Cunha Paiva ${ }^{1}\left(\right.$, Daniel Simões Oliveira ${ }^{2}$ and Leandro Wang Hantao ${ }^{1, *}$ \\ 1 Institute of Chemistry, University of Campinas, Campinas, SP 13083-970, Brazil; cunhapaiva@gmail.com \\ 2 Confra da Mantiqueira, Córrego do Bom Jesus, MG 37605-000, Brazil; profdsimoes@gmail.com \\ * Correspondence: wang@unicamp.br; Tel.: +55-019-3521-3083
}

Received: 10 May 2019; Accepted: 19 August 2019; Published: 25 September 2019

\begin{abstract}
In this study, we report the combination of comprehensive two-dimensional gas chromatography $(\mathrm{GC} \times \mathrm{GC})$ with multivariate pattern recognition through template matching for the assignment of the contribution of Brazilian Ale 02 yeast strain to the aroma profile of beer compared with the traditional Nottingham yeast. Volatile organic compounds (VOC) from two beer samples, which were fermented with these yeast strains were sampled using headspace solid-phase microextraction (HS-SPME). The aroma profiles from both beer samples were obtained using GC $\times$ GC coupled to a fast scanning quadrupole mass spectrometer. Data processing performed through multiway principal components analysis succeeded in separating both beer samples based on yeast strain. The execution of a simple and reliable procedure succeeded and identified 46 compounds as relevant for sample classification. Furthermore, the bottom-up approach spotted compounds found exclusively in the beer sample fermented with the Brazilian yeast, highlighting the bioaromatization properties introduced to the aroma profile by this yeast strain.
\end{abstract}

Keywords: foodomics; Brazilian yeast; craft beer; sensomics

\section{Introduction}

The Brazilian beer market has been in the spotlight due to steady increase in beer consumption over the past few decades [1]. In this context, the search for better quality beers and new varieties of the raw materials (malt, water, hops and yeast) is fundamental. Additionally, new ingredients have been tested during brewing to produce unique beers with innovative flavor compounds [2].

Flavor compounds are characterized by their interaction with human olfactory system and it is through such chemistry that specific odor sensations are induced. Volatile organic compounds (VOC) are directly involved in the flavor sensation of beers. The chemical nature of VOC that are associated with flavor and aroma in beer is varied, including esters, aliphatic and aromatic alcohols, carbonyl-containing compounds and terpenoids [3,4]. Hence, beer is considered a complex matrix, even though the majority (92-95\%) of the beverage is water [5]. Several qualitative studies have tried to profile the composition of beers, whether to characterize the VOC profile or to search for specific markers in aged beer [3,6-9].

The art of brewing involves careful control of several stages, and a paramount one is the fermentation, i.e., bioaromatization. Fermentation involves the addition of yeasts to the recipe to convert the sugars in ethanol and introduce aroma-related compounds derived from biological channels from the yeast's metabolism. Accordingly, important factors that can influence this metabolic balance include temperature, $\mathrm{pH}$ and yeast strain [5]. 
Research on non-conventional yeasts has taken place to effectively develop novel aroma profiles through bioaromatization [10]. Recently, a local startup (Yeastlab-Franca, Brazil) isolated a unique yeast strain from Plinia cauliflora (i.e., jabuticaba, a "Brazilian berry") peel that could be used for beer production, which was named Brazilian Ale 02 yeast. Furthermore, to the best of our knowledge there are no reports evaluating the outcome of the bioaromatization properties of Brazilian Ale 02 yeast strain to the aroma profile of a beer.

The bioaromatization properties study of Brazilian Ale 02 yeast should be driven using appropriate sample preparation, which mitigates production of artifacts, to guarantee reliable results. Solid-phase microextraction (SPME) [11] fits these requirements since it eliminates the use of solvents and combines analyte isolation and pre-concentration into one simple step. The technique has been popular to analyze food products, including wine, cheese and beer [12]. Reports involving beer analysis usually use headspace solid-phase microextraction (HS-SPME) for targeted analysis. Headspace analysis is very beneficial to extent SPME fiber lifetime since non-volatile compounds such as sugars, proteins and polyphenols present in the beer are avoided in the extraction, which could damage the sorbent phase during direct immersion (DI) $[13,14]$. A wide variety of coatings can be used as extracting phases in SPME. Some reports applied a mixed fiber for beer analysis, i.e., divinylbenzene/carboxen/polydimethylsiloxane (DVB/CAR/PDMS), in which analyte adsorption dominates analyte sorption. These reports covered characterization of the VOC profile, off-flavors research or quantitation $[9,12,15]$, demonstrating high reproducibility either in manual or automated methods [12].

Standard practices for VOC profiling in beers used conventional gas chromatography (1D-GC) [8,9,15-20]. However, peak overlap severely dampens qualitative and quantitative analyses in such complex samples [21]. Flow-modulated comprehensive two-dimensional gas chromatography coupled to mass spectrometry (FM-GC $\times$ GC-MS) enables proper sample separation and characterization due to the enhanced peak capacity of the composite system. Such technique uses two consecutive stages of separation with distinct selectivity. FM has been increasingly attractive to expert and non-expert users because of its operational simplicity, and capability to modulate compounds from a broad volatility range. Griffith et al. [22] demonstrated the increased peak capacity of differential flow modulation GC $\times$ GC. The report using reverse fill/flush (RFF) modulation showed the excellent precision and capacity to handle significant overloading peaks that exhibited poor peak shape and performance in forward fill/flush (FFF) modulation. Moreover, RFF modulation enables cost-effective and robust analysis, bridging the gap between powerful instrumentation and routine analysis.

Martins et al. [23] made use of GC $\times$ GC to trace the terpenic composition of 18 lager beers, revealing the presence of 94 mono and sesquiterpenic compounds. The second dimension was important to resolve key compounds such as 1,1,3,5-tetra-methylcyclohexane and $\beta$-ocimene. Similarly, GC×GC [4] allowed the assignment of 32 VOC related to beer aroma from Portuguese samples.

Chromatograms generated by FM-GC $\times$ GC-MS are structurally complex (i.e., four-way data) and contain a lot of information; thus, it is important to work with an appropriate data processing technique capable of extracting all meaningful and context-oriented information. Multiway principal components analysis (MPCA) is a well-established multivariate statistical method for data processing, which enables pixel-based pattern recognition [24].

In this article, we applied a bottom-up approach involving FM-GC XGC-MS and MPCA for assignment of yeast related volatile organic compounds in two beer samples fermented with distinguished yeast strains. Data processing had the aim of highlighting compounds that could be used to differentiate both beer samples. 


\section{Materials and Methods}

\subsection{Samples}

Fresh beer samples were kindly provided by a local company (Cervejaria Confra da Mantiqueira-Campinas, Brazil). Comparative analysis was enabled by standardizing the brewing process. Brewing started from the same wort, which presented $14 \%$ of maltose as its original extract (OE). Fermentation/bioaromatization step lasted 7 days at $20^{\circ} \mathrm{C}$ followed by a cold maturation step at $2{ }^{\circ} \mathrm{C}$ for 7 days. Sample uniqueness was established in the yeast strain used; each beer was fermented with a distinguished yeast strain. The yeast strains were the traditional Nottingham yeast (Lallemand-Montreal, QC, Canada) and the unique Brazilian Ale 02 (Yeastlab Biotecnologia-Franca, Brazil). For discussion purposes, the beer produced with the Brazilian yeast will be named "BR" and with the English yeast will be named "ENG". The samples were $\mathrm{CO}_{2}$ capped in amber bottles and stored in the refrigerator $\left(4^{\circ} \mathrm{C}\right)$ for up to 14 days. Analysis was performed immediately after opening the sample.

\subsection{Materials and Extraction Devices}

The linear temperature programmed retention indices (LTPRI) of the analytes were determined using a standard mixture of $\mathrm{C}_{8}-\mathrm{C}_{20}$ n-alkanes (04070-1ML) (Merck-St. Louis, MO, USA). A 2-cm SPME fiber coated with 50/30 $\mu \mathrm{m}$ DVB/CAR/PDMS (57299-U) was used for analyte extraction (Merck). Magnetic screw caps with PTFE-PDMS septa (SU860101) and $20 \mathrm{~mL}$ glass vials (SU860097) (Merck) were used in the SPME extractions.

\subsection{Solid-Phase Microextraction Method}

The DVB/CAR/PDMS fiber was conditioned as recommended by the manufacturer. Sample degassing was performed using ultrasound for $10 \mathrm{~min}$ at room temperature. After degassing, $5 \mathrm{~mL}$ aliquots of beer were added to $20 \mathrm{~mL}$ vials. The vials contained pre-weighted $1.75 \mathrm{~g}$ of sodium chloride [17]. The samples were immediately stored in the refrigerator $\left(-2{ }^{\circ} \mathrm{C}\right)$. Prior to extraction, a pre-equilibrium step of $20 \mathrm{~min}$ at $45^{\circ} \mathrm{C}$ was applied. To ensure optimum extraction of VOC, an extraction profile was evaluated between 5 to $45 \mathrm{~min}$ at $45^{\circ} \mathrm{C}$. Longer extraction times were not evaluated to improve sample throughput. The agitation was maintained continuously at $500 \mathrm{rpm}$ to ensure fast mass transfer between sample and HS. Four replicates were obtained for each sample. After extraction, sample introduction to the GC was attained by thermal desorption at the inlet, which operated in splitless mode at $260^{\circ} \mathrm{C}$ with a sampling time of $1 \mathrm{~min}$.

\subsection{Gas Chromatography}

The GC $\times$ GC analyses were performed on a flow-modulated instrument that comprised a TRACE 1300 gas chromatograph coupled with a fast scanning ISQ single quadrupole mass spectrometer (QMS) (Thermo Fisher Scientific-Waltham, MA, USA). The GC $\times$ GC was fitted with a split/splitless injector, which operated in splitless mode at $260^{\circ} \mathrm{C}$. The INSIGHT interface (SepSolve Analytical-Peterborough, UK) was used to perform differential flow modulation using the reverse fill/flush configuration. ChromSpace (SepSolve Analytical) was used to synchronize and control the INSIGHT modulator. Instrument control and data acquisition was performed using Xcalibur (Thermo Scientific-Waltham, MA, USA) software.

Column set consisted of two wall-coated open tubular (WCOT) capillary columns. The primary column was a $30 \mathrm{~m} \times 0.25 \mathrm{~mm}$-id $(0.25 \mu \mathrm{m} ; \beta$ of 250) MEGA-5HT (MEGA srl-Legnano, Italy). The secondary column was a $5 \mathrm{~m} \times 0.25 \mathrm{~mm}$-id $(0.25 \mu \mathrm{m} ; \beta$ of 250$) \mathrm{HP}-50+$ (Agilent Technologies-Santa Clara, CA, USA). Oven temperature ramp was programmed from $45^{\circ} \mathrm{C}(3 \mathrm{~min})$ to $270{ }^{\circ} \mathrm{C}$ at $3{ }^{\circ} \mathrm{C} \mathrm{min}{ }^{-1}$. Modulation period was set to $6.0 \mathrm{~s}$ with a re-injection (flush) pulse of $200 \mathrm{~ms}$. A sampling loop of $50 \mu \mathrm{L}$ was used for GC $\times$ GC modulation. Helium was used as auxiliary and carrier gas at constant flow rates of $12.5 \mathrm{~mL} / \mathrm{min}$ and $1.00 \mathrm{~mL} / \mathrm{min}$, respectively. The mass range was set from 50 to $350 \mathrm{~m} / \mathrm{z}$ units at 
42 scans s $^{-1}$. Transfer line was operated at $250{ }^{\circ} \mathrm{C}$ and ion source at $200{ }^{\circ} \mathrm{C}$. Electron ionization was performed at $70 \mathrm{eV}$ and $150 \mu \mathrm{A}$.

\subsection{Identification}

GC Image (Zoex-Houston, TX, USA) was used for tentative identification of analytes by combining mass spectrum similarity searches and LTPRI filtering. Blob detection was done by setting the following parameters in GC Image: minimum area of 20, minimum volume of 50 and minimum peak value of 50 . Tentative identification was executed by adopting minimum similarity match of $80 \%$ and \pm 25 LTPRI deviation from NIST. Qualitative analysis was performed using NIST14 MS library (National Institute of Standards-Gaithersburg, MD, USA). The Good Scents Company was used to obtain the odor and flavor descriptors.

\subsection{Pixel-Based Chemometric Analysis}

The '.raw' Xcalibur (Thermo Scientific) native files were converted to '.cdf' ANDI/netCDF format using the File Converter plug-in. MATLAB R2017b (MathWorks-Natick, MA, USA) environment was used to perform multivariate data analysis. The netCDF files were imported to MATLAB to generate three-way data tensors. For additional detail on three-way data tensors refer to [25,26]. PLS Toolbox 7.5 (Eigenvector Research Inc.-Wenatchee, WA, USA) was used to perform the MPCA analysis and to highlight the relevant chemical information for sample classification based on yeast strain.

\section{Results and Discussions}

\subsection{SPME Optimization}

To guarantee the higher extraction rate with shortest time, the extraction profile was determined and the extraction time during SPME optimized for a representative beer. As shown in Figure 1, five extraction times were evaluated and total volume of peaks were used as response parameter to ensure adequate transfer of the analytes from the sample matrix to the extracting phase.

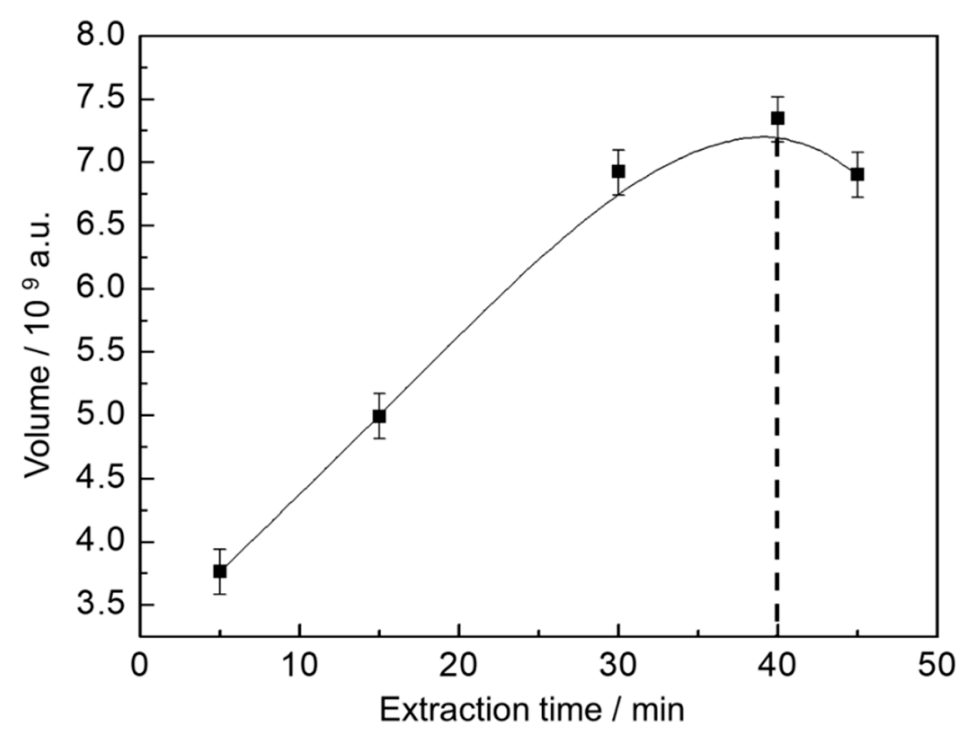

Figure 1. Extraction profile of volatile and semi-volatile organic compounds (VOC) from beer. The response is presented as the sum of the peak volumes from the GC×GC chromatogram.

The extraction profile reveals that the equilibration time for the analytes is reached within 40 min of extraction, after that the amount of analyte extracted is about the same. Therefore, to ensure sample throughput, extraction time was fixed in $40 \mathrm{~min}$. 


\subsection{VOC Tracing Using GC $\times G C$}

Beer production involves a considerable number of important steps, which presents many variables that can affect the final composition of the beverage if they fluctuate from the expected values. A small fluctuation during beer production can be responsible for relevant changes between the ratio of its components or the presence of unique ones in the perceived flavor, altering the volatile organic compounds and organoleptic profile of the beer. The chromatograms obtained for BR and ENG beer samples, exhibited in Figure 2, shows the presence of approximately 210 compounds in the beer aroma. Main chemical classes of analytes, see Table 1, include alcohols, terpenoids, organic acids and esters, which are corroborated by previous findings $[3,4]$.

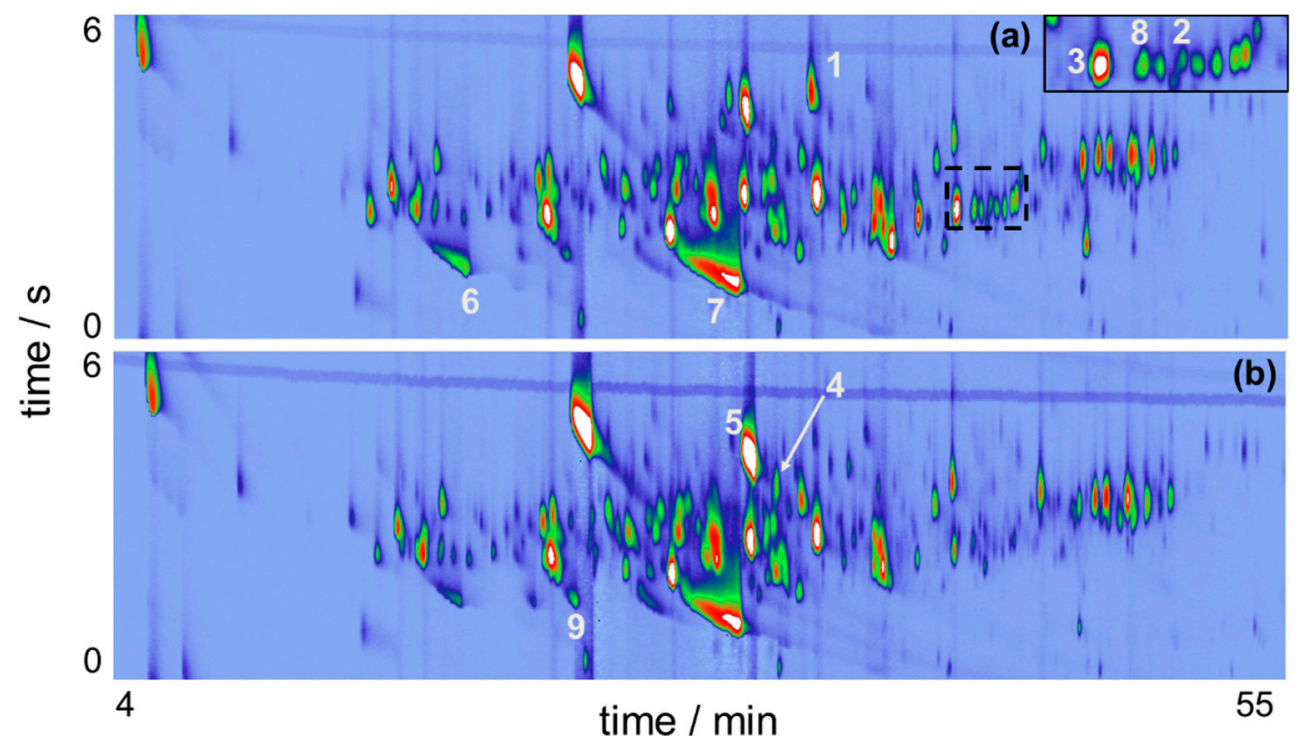

Figure 2. GC $\times$ GC-QMS chromatograms for two craft beer samples using HS-SPME and sampling with DVB/CAR/PDMS (a) BR sample; (b) ENG sample. BR corresponds to the beer brewed with the Brazilian Ale 02 yeast and ENG corresponds to the beer brewed with the Nottingham yeast.

Esters are important contributors to flavor and in general are present in concentrations around their threshold, which means that minor changes in their concentration may dramatically affect beer flavor $[27,28]$. Usually they are compounds that impart a sweet-fruity aroma to beers and among them the ones with proven aroma activity can be synthesized intracellularly by fermenting yeast cells. The volatile portion of these compounds are produced in an enzyme-catalyzed condensation reaction between an activated fatty acid (acyl-Coa) and a higher alcohol [28]. Esters detected in the beer samples include 2-phenylethyl acetate and perillyl acetate, with first one contributing to honey attributes and the second one associated with woody and raspberry notes. Figure 2 also reveals a region, indicated by the dashed area between $40-46 \mathrm{~min}$, with notable differences between the samples, with BR sample exhibiting compounds with higher intensities than ENG; among them are aromadendrene (analyte \#2), which is associated with woody notes. Important terpene hydrocarbons also identified are $\gamma$-muurolene (analyte \#8), responsible for herbal and spicy attributes, and $\alpha$-humulene (analyte \#3) a hop oil compound that impart woody notes in the aroma profile.

Another chemical class that plays an important role in the aromatic profile of beers are volatile phenols. 4-vinylguaiacol and 4-vinylphenol are the main phenols that impart flavor in beer. Usually their presence must be controlled, otherwise surpassing a specific concentration they are considered off-flavors that negatively affect beer quality [9,29]. 4-vinylguaiacol (analyte \#1) exhibits a higher intensity in the BR sample, imparting a sweet smoky attribute to the organoleptic profile. Conversely, ENG sample exhibits higher intensities for methyl 2-nonynoate (analyte \#4), a flavoring related 
substance that contributes with floral and tropical fruity notes, and 2-phenylethyl acetate (analyte \#5) that imparts honey and floral rosy attributes.

These findings are corroborated by previous studies of the VOC profile of beers $[16,23,30]$. As a matter of fact, it is important to highlight that although approximately 210 peaks were detected in the chromatograms, only $79(\sim 38 \%)$ were successfully identified based on the selected qualitative parameters ( $80 \%$ of similarity and \pm 25 LTPRI deviation from NIST Web Book). This highlights the need to couple GC $\times \mathrm{GC}$ with high accuracy mass spectrometers to complement qualitative analyses.

It should be noted that hexanoic acid (analyte \#6), heptanoic acid (analyte \#9) and octanoic acid (analyte \#7) were successfully identified, although their peaks exhibited deviations higher than 25 LTPRI units. Identification was confirmed by evaluating their peak shapes in the chromatograms and similarities between their experimental mass spectrums and NIST database. Figure 2 reveals the presence of pronounced peak tailing in the first dimension for these organic acids, two reasons are identified as responsible for it. First, slow mass transfer of the analytes from the SPME fiber to the GC column [31]. Second, peak tailing is related to non-linear chromatography of organic acids using a non-polar stationary phase used in the first dimension, a MEGA-5HT capillary column.

Figure 2 also exhibits the benefits that comprehensive two-dimensional gas chromatography brings to the analyses, mitigating possible co-elution between chromatographic peaks, which are resolved in the second dimension. For example, Figure 3 focuses on one of these regions of the chromatograms for BR sample.

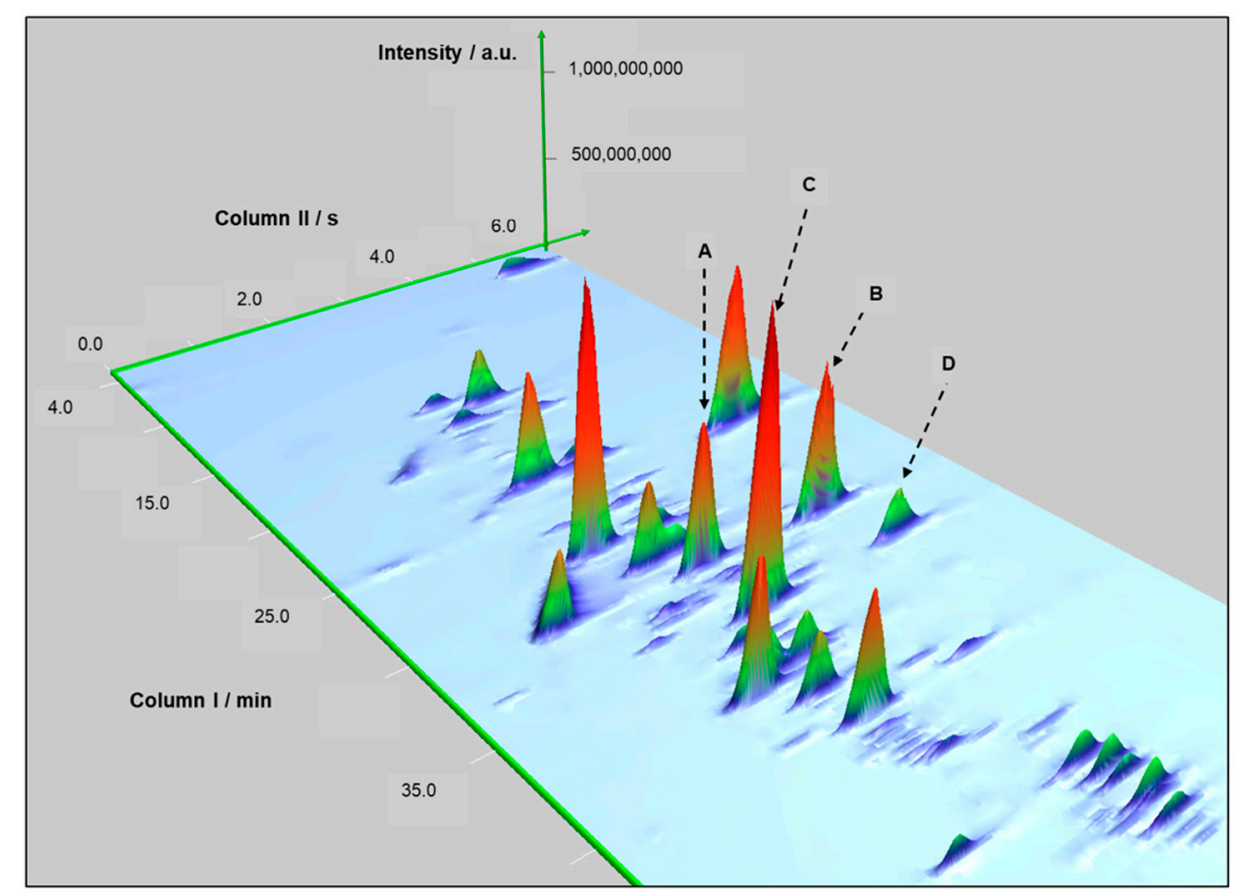

Figure 3. Example of resolved peaks in the second dimension of the chromatograms for BR. Second dimension resolved trans-geraniol (peak A) and 2-phenylethyl acetate (peak B). Additionally, (E)-methyl geranate (peak C) and 4-vinylguaiacol (peak D).

The selected region reveals the gain in resolution obtained due to increased peak capacity of the composite 2D-GC analysis. The second dimension mitigated the co-elution between trans-geraniol (peak A) and 2-phenylethyl acetate (peak B). In addition, (E)-methyl geranate (peak C) and 4-vinylguaiacol (peak D) were resolved in ${ }^{2} \mathrm{D}$.

Although visual inspection of the chromatograms reveals variations between the chromatographic profile of the BR and ENG samples, to ensure that all the chemical information provided by the GC $\times$ GC-QMS will be properly analyzed, an appropriate data handling technique is necessary. Furthermore, as GC $\times$ GC-MS is an analytical technique that produces structurally complex and 
dense data, it is also important to guarantee that relevant information will not be lost or overlooked during data processing. Then, with the aim of an unbiased assessment during identification of compounds produced due to the use of the unique yeast strain, computational tools and a multivariate technique were required for proper pattern recognition.

\subsection{Chemometrics}

Development of an adequate protocol to evaluate BR and ENG beers was accomplished by MPCA. The main idea was to extract data information by using a multiway exploratory method, which benefits from all the available data dimensions and results in useful and easily understood plots. Principal components (PC) are generated based on the explained information extracted from the original data, with the first PC explaining most of the data variance and subsequent components explaining progressively less of the remaining variance [24].

In this pixel-based chemometric analysis four replicates from the same BR beer sample and four replicates from the same ENG beer sample form the sample group, and each variable refers to a pixel of the chromatogram's data obtained after raw data handling in MATLAB environment. MPCA basically decomposes the data into what is called scores and loadings. Through the scores information it is possible to identify the patterns within the samples, while the loadings can be used to pinpoint the chromatographic peaks responsible for such patterns.

The scores graph of total ion chromatogram (TIC) from PC1 and PC2, seen in Figure 4, reveals important information for pattern recognition. Its analysis reveals the presence of distinct traits between the VOC profile of BR and ENG beer samples. In this case, the information within PC1 is able to distinguish the samples groups (BR and ENG).

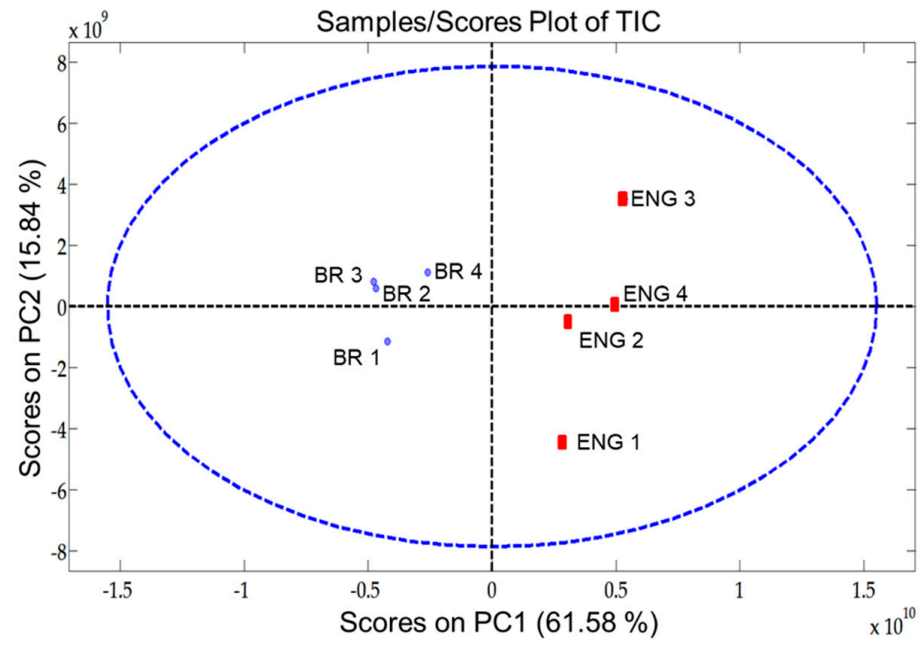

Figure 4. Scores plot of pixel-based two component Multiway principal components analysis (MPCA) from beer samples evaluated (BR and ENG) using the four-way data from GC×GC-QMS.

The loading's graph can be used to elucidate the variables/pixels that contributed to the pattern evidenced in Figure 4. For additional detail on template matching refer to Reference [32]. This information enables targeting the analytes that are responsible for beer differentiation and establishing the contributions the unique Brazilian Ale 02 yeast strain brought to the VOC profile of the beer. As the BR samples are found in the negative part of PC1, loadings with negative values cover the VOC that are present in higher intensities in BR samples in comparison with ENG. By selecting the negative weights from the loadings of PC1, it was possible to plot a virtual chromatogram, which highlighted the peaks that differentiated BR and ENG samples. This virtual chromatogram was then used to create a template using GC Image software, Figure 5a. After creating the template, it was matched and applied onto the real sample chromatograms of BR samples. Hence, the analytes that varied the most between BR and ENG beer were identified, as shown in Figure 5b. 
Table 1. Analytes identified in the volatile and semi-volatile fraction of the ENG and BR samples by HS-SPME and GC $\times$ GC-QMS. Linear temperature programmed retention index (LTPRI) were obtained from NIST. All analytes were identified by considering a minimum similarity match of 800 and a \pm 25 LTPRI deviation from NIST Web Book. The detection of volatile organic compounds in BR and ENG samples is also indicated. Template matching refers to the assignment of class-specific peaks using a mixed data analysis approach, namely, multiway principal component analysis and template matching. The odor and flavor attribution were acquired from The Good Scents Company [33].

\begin{tabular}{|c|c|c|c|c|c|c|c|c|c|c|c|}
\hline \multirow[t]{2}{*}{ Compound } & \multirow[t]{2}{*}{ Formula } & \multirow[t]{2}{*}{ CAS } & \multirow[t]{2}{*}{ Match } & \multicolumn{2}{|c|}{ LTPRI } & \multicolumn{2}{|c|}{ Detection } & \multicolumn{2}{|c|}{$\begin{array}{l}\text { Template } \\
\text { Matching }\end{array}$} & \multirow[t]{2}{*}{ Odor } & \multirow[t]{2}{*}{ Flavor } \\
\hline & & & & Exp & NIST & BR & ENG & BR & ENG & & \\
\hline isoamyl acetate & $\mathrm{C}_{7} \mathrm{H}_{14} \mathrm{O}_{2}$ & $123-92-2$ & 885 & 841 & 876 & $\mathrm{x}$ & $\mathrm{x}$ & $\mathrm{x}$ & $\mathrm{x}$ & $\begin{array}{l}\text { sweet, fruity, banana } \\
\text { solvent }\end{array}$ & $\begin{array}{l}\text { sweet, fruity, banana-like with } \\
\text { a green ripe nuance }\end{array}$ \\
\hline $\begin{array}{l}\text { 2-methylpropyl } \\
\text { isobutyrate }\end{array}$ & $\mathrm{C}_{8} \mathrm{H}_{16} \mathrm{O}_{2}$ & $97-85-8$ & 832 & 898 & 910 & $\mathrm{x}$ & $\mathrm{x}$ & - & - & $\begin{array}{l}\text { ethereal fruity, tropical } \\
\text { fruit, pineapple, banana }\end{array}$ & $\begin{array}{l}\text { fruity, pineapple, tropical } \\
\text { fruit, ripe fruit }\end{array}$ \\
\hline $\begin{array}{c}\text { pentyl } \\
\text { propionate }\end{array}$ & $\mathrm{C}_{8} \mathrm{H}_{16} \mathrm{O}_{2}$ & $624-54-4$ & 806 & 973 & 969 & - & $\mathrm{x}$ & - & - & $\begin{array}{l}\text { sweet, fruity, apricot, } \\
\text { pineapple }\end{array}$ & - \\
\hline ß-pinene & $\mathrm{C}_{10} \mathrm{H}_{16}$ & $127-91-3$ & 890 & 989 & 979 & $\mathrm{x}$ & $\mathrm{x}$ & $\mathrm{x}$ & - & $\begin{array}{l}\text { dry, woody, resinous pine } \\
\text { and hay green }\end{array}$ & $\begin{array}{l}\text { fresh, piney and woody, terpy } \\
\text { and resinous with a slight } \\
\text { minty, camphoraceous with a } \\
\text { spicy nuance }\end{array}$ \\
\hline B-myrcene & $\mathrm{C}_{10} \mathrm{H}_{16}$ & $123-35-3$ & 849 & 990 & 991 & - & $x$ & - & - & $\begin{array}{l}\text { peppery, terpene spicy, } \\
\text { balsam }\end{array}$ & $\begin{array}{l}\text { woody, citrus, fruity with a } \\
\text { tropical mango and slight } \\
\text { leafy minty nuances }\end{array}$ \\
\hline ethyl hexanoate & $\mathrm{C}_{8} \mathrm{H}_{16} \mathrm{O}_{2}$ & $123-66-0$ & 859 & 1003 & - & $\mathrm{x}$ & $\mathrm{x}$ & $\mathrm{x}$ & - & $\begin{array}{l}\text { sweet, fruity, pineapple, } \\
\text { waxy, green and banana }\end{array}$ & $\begin{array}{l}\text { sweet, pineapple, fruity, waxy } \\
\text { and banana with a green estry } \\
\text { nuance }\end{array}$ \\
\hline hexanoic acid & $\mathrm{C}_{6} \mathrm{H}_{12} \mathrm{O}_{2}$ & $142-62-1$ & 873 & 1045 & 990 & $\mathrm{x}$ & $\mathrm{x}$ & $x$ & - & $\begin{array}{l}\text { sour, fatty, sweat and } \\
\text { cheese }\end{array}$ & $\begin{array}{l}\text { cheesy, fruity, phenolic fatty } \\
\text { goaty }\end{array}$ \\
\hline B-ocimene & $\mathrm{C}_{10} \mathrm{H}_{16}$ & $13877-91-3$ & 828 & 1052 & 1037 & - & $\mathrm{x}$ & - & - & $\begin{array}{l}\text { citrus, tropical green } \\
\text { terpene, woody green }\end{array}$ & $\begin{array}{l}\text { green, tropical, woody with } \\
\text { floral and vegetable nuances }\end{array}$ \\
\hline $\begin{array}{c}\text { ethyl } \\
\text { 5-methylhexanoate }\end{array}$ & $\mathrm{C}_{9} \mathrm{H}_{18} \mathrm{O}_{2}$ & $10236-10-9$ & 857 & 1067 & 1072 & $\mathrm{x}$ & $\mathrm{x}$ & - & - & - & - \\
\hline linalool oxide & $\mathrm{C}_{10} \mathrm{H}_{18} \mathrm{O}_{2}$ & 5989-33-3 & 843 & 1076 & 1074 & $\mathrm{x}$ & $\mathrm{x}$ & - & - & earthy floral, sweet woody & - \\
\hline hop ether & $\mathrm{C}_{10} \mathrm{H}_{16} \mathrm{O}$ & 19901-95-2 & 869 & 1100 & - & $x$ & $\mathrm{x}$ & $x$ & $x$ & - & - \\
\hline linalool & $\mathrm{C}_{10} \mathrm{H}_{18} \mathrm{O}$ & 78-70-6 & 899 & 1107 & 1099 & $\mathrm{x}$ & $\mathrm{x}$ & $\mathrm{x}$ & $\mathrm{x}$ & $\begin{array}{l}\text { citrus, floral woody, green } \\
\text { and blueberry }\end{array}$ & $\begin{array}{l}\text { citrus, orange, lemon, floral, } \\
\text { waxy, aldehydic and woody }\end{array}$ \\
\hline heptanoic acid & $\mathrm{C}_{7} \mathrm{H}_{14} \mathrm{O}_{2}$ & $111-14-8$ & 834 & 1125 & 1078 & $\mathrm{x}$ & $\mathrm{x}$ & - & - & rancid, sour, cheesy, sweat & $\begin{array}{l}\text { waxy, cheesy, fruity, dirty and } \\
\text { fatty }\end{array}$ \\
\hline
\end{tabular}


Table 1. Cont

\begin{tabular}{|c|c|c|c|c|c|c|c|c|c|c|c|}
\hline \multirow[t]{2}{*}{ Compound } & \multirow[t]{2}{*}{ Formula } & \multirow[t]{2}{*}{ CAS } & \multirow[t]{2}{*}{ Match } & \multicolumn{2}{|c|}{ LTPRI } & \multicolumn{2}{|c|}{ Detection } & \multicolumn{2}{|c|}{$\begin{array}{l}\text { Template } \\
\text { Matching }\end{array}$} & \multirow[t]{2}{*}{ Odor } & \multirow[t]{2}{*}{ Flavor } \\
\hline & & & & $\operatorname{Exp}$ & NIST & BR & ENG & BR & ENG & & \\
\hline fenchol & $\mathrm{C}_{10} \mathrm{H}_{18} \mathrm{O}$ & $1632-73-1$ & 828 & 1127 & - & $\mathrm{x}$ & - & - & - & $\begin{array}{l}\text { camphor borneol pine, } \\
\text { woody, dry, sweet, lemon }\end{array}$ & $\begin{array}{l}\text { camphoreous cooling } \\
\text { medicinal minty, earthy } \\
\text { humus }\end{array}$ \\
\hline trans-pinocarveol & $\mathrm{C}_{10} \mathrm{H}_{16} \mathrm{O}$ & 547-61-5 & 864 & 1149 & - & $\mathrm{x}$ & $\mathrm{x}$ & $\mathrm{x}$ & $\mathrm{x}$ & $\begin{array}{l}\text { warm, woody and } \\
\text { balsamic fennel }\end{array}$ & - \\
\hline cis-isocarveol & $\mathrm{C}_{10} \mathrm{H}_{16} \mathrm{O}$ & $22626-43-3$ & 821 & 1166 & - & $x$ & $x$ & - & - & - & - \\
\hline $\begin{array}{l}\text { 2,6-dimethyl-1,5,7- } \\
\text { octatrien-3-ol }\end{array}$ & $\mathrm{C}_{10} \mathrm{H}_{16} \mathrm{O}$ & $29414-56-0$ & 808 & 1168 & - & - & $\mathrm{x}$ & $x$ & $x$ & camphoreous lime & - \\
\hline borneol & $\mathrm{C}_{10} \mathrm{H}_{18} \mathrm{O}$ & 507-70-0 & 811 & 1181 & 1167 & $\mathrm{x}$ & - & - & - & $\begin{array}{l}\text { pine, woody, camphor } \\
\text { balsamic }\end{array}$ & - \\
\hline terpinen-4-ol & $\mathrm{C}_{10} \mathrm{H}_{18} \mathrm{O}$ & $562-74-3$ & 825 & 1187 & 1177 & $x$ & $x$ & - & - & $\begin{array}{l}\text { pepper, woody, earth } \\
\text { musty sweet }\end{array}$ & $\begin{array}{l}\text { cooling, woody, earthy, clove } \\
\text { spicy with a citrus undernote }\end{array}$ \\
\hline ethyl octanoate & $\mathrm{C}_{10} \mathrm{H}_{20} \mathrm{O}_{2}$ & $106-32-1$ & 911 & 1201 & 1196 & $\mathrm{x}$ & $x$ & $\mathrm{x}$ & $x$ & $\begin{array}{l}\text { fruity, wine, waxy, sweet } \\
\text { apricot, banana brandy } \\
\text { and pear }\end{array}$ & $\begin{array}{l}\text { sweet, waxy, fruity and } \\
\text { pineapple with creamy, fatty, } \\
\text { mushroom and cognac notes }\end{array}$ \\
\hline terpineol & $\mathrm{C}_{10} \mathrm{H}_{18} \mathrm{O}$ & $98-55-5$ & 857 & 1206 & 1196 & $x$ & $x$ & - & $\mathrm{x}$ & $\begin{array}{l}\text { pine, terpene, lilac citrus, } \\
\text { woody, floral }\end{array}$ & $\begin{array}{l}\text { citrus, woody with a lemon } \\
\text { and lime nuance. it has a } \\
\text { slight soapy mouth feel }\end{array}$ \\
\hline myrtenol & $\mathrm{C}_{10} \mathrm{H}_{16} \mathrm{O}$ & 515-00-4 & 823 & 1207 & 1195 & - & $\mathrm{x}$ & - & - & $\begin{array}{l}\text { woody, pine, balsam } \\
\text { sweet, mint }\end{array}$ & $\begin{array}{l}\text { cooling, minty, camphoreous, } \\
\text { green with a medicinal } \\
\text { nuance }\end{array}$ \\
\hline cis-geraniol & $\mathrm{C}_{10} \mathrm{H}_{18} \mathrm{O}$ & $106-25-2$ & 833 & 1236 & - & $\mathrm{x}$ & $\mathrm{x}$ & - & $\mathrm{x}$ & $\begin{array}{l}\text { sweet, neroli, citrus, } \\
\text { magnolia }\end{array}$ & $\begin{array}{l}\text { lemon, bitter, green and fruity } \\
\text { with a terpy nuance }\end{array}$ \\
\hline citronellol & $\mathrm{C}_{10} \mathrm{H}_{20} \mathrm{O}$ & 1117-61-9 & 877 & 1238 & - & $\mathrm{x}$ & $\mathrm{x}$ & $\mathrm{x}$ & $\mathrm{x}$ & $\begin{array}{l}\text { citronella oil, rose leaf and } \\
\text { oily petal }\end{array}$ & - \\
\hline $\begin{array}{c}\text { ethyl } \\
\text { phenylacetate }\end{array}$ & $\mathrm{C}_{10} \mathrm{H}_{12} \mathrm{O}_{2}$ & $101-97-3$ & 815 & 1252 & 1246 & $\mathrm{x}$ & - & $x$ & - & $\begin{array}{l}\text { sweet, floral, honey, rose } \\
\text { and balsam cocoa }\end{array}$ & $\begin{array}{l}\text { strong sweet rosy honey and } \\
\text { balsamic cocoa-like with } \\
\text { molasses and yeasty nuances }\end{array}$ \\
\hline octanoic acid & $\mathrm{C}_{8} \mathrm{H}_{16} \mathrm{O}_{2}$ & $124-07-2$ & 911 & 1257 & 1180 & $\mathrm{x}$ & $\mathrm{x}$ & $x$ & $\mathrm{x}$ & $\begin{array}{l}\text { fatty, waxy, rancid oily, } \\
\text { vegetable cheesy }\end{array}$ & $\begin{array}{l}\text { rancid soapy, cheesy, fatty } \\
\text { brandy }\end{array}$ \\
\hline trans-geraniol & $\mathrm{C}_{10} \mathrm{H}_{18} \mathrm{O}$ & $106-24-1$ & 930 & 1263 & - & $x$ & $x$ & $\mathrm{x}$ & $x$ & $\begin{array}{l}\text { sweet, floral, fruity, rose, } \\
\text { waxy and citrus }\end{array}$ & $\begin{array}{l}\text { floral, rosy, waxy and } \\
\text { perfume with a fruity, } \\
\text { peach-like nuance }\end{array}$ \\
\hline
\end{tabular}


Table 1. Cont

\begin{tabular}{|c|c|c|c|c|c|c|c|c|c|c|c|}
\hline \multirow[t]{2}{*}{ Compound } & \multirow[t]{2}{*}{ Formula } & \multirow[t]{2}{*}{ CAS } & \multirow[t]{2}{*}{ Match } & \multicolumn{2}{|c|}{ LTPRI } & \multicolumn{2}{|c|}{ Detection } & \multicolumn{2}{|c|}{$\begin{array}{l}\text { Template } \\
\text { Matching }\end{array}$} & \multirow[t]{2}{*}{ Odor } & \multirow[t]{2}{*}{ Flavor } \\
\hline & & & & Exp & NIST & BR & ENG & BR & ENG & & \\
\hline $\begin{array}{l}\text { 2-phenylethyl } \\
\text { acetate }\end{array}$ & $\mathrm{C}_{10} \mathrm{H}_{12} \mathrm{O}_{2}$ & $103-45-7$ & 935 & 1266 & 1255 & $\mathrm{x}$ & $\mathrm{x}$ & - & $\mathrm{x}$ & $\begin{array}{l}\text { floral, rose, sweet, honey, } \\
\text { fruity tropical }\end{array}$ & $\begin{array}{l}\text { sweet, honey, floral, rosy with } \\
\text { a slight green nectar fruity } \\
\text { body and mouth feel }\end{array}$ \\
\hline $\begin{array}{l}\text { 2-isopropenyl-5- } \\
\text { methylhex-4-enal }\end{array}$ & $\mathrm{C}_{10} \mathrm{H}_{16} \mathrm{O}$ & - & 832 & 1280 & - & - & $x$ & - & - & - & - \\
\hline $\begin{array}{l}\text { 3-nonenoic acid, } \\
\text { ethyl ester }\end{array}$ & $\mathrm{C}_{11} \mathrm{H}_{20} \mathrm{O}_{2}$ & $91213-30-8$ & 805 & 1286 & - & $\mathrm{x}$ & $x$ & - & - & - & - \\
\hline trans-shisool & $\mathrm{C}_{10} \mathrm{H}_{18} \mathrm{O}$ & $22451-48-5$ & 885 & 1288 & - & $\mathrm{x}$ & $\mathrm{x}$ & $\mathrm{x}$ & - & - & - \\
\hline (Z)-3-decen-1-ol & $\mathrm{C}_{10} \mathrm{H}_{20} \mathrm{O}$ & $10340-22-4$ & 807 & 1290 & - & - & $x$ & - & - & - & - \\
\hline 1,10-decanediol & $\mathrm{C}_{10} \mathrm{H}_{22} \mathrm{O}_{2}$ & $112-47-0$ & 812 & 1290 & - & $x$ & - & - & $x$ & - & - \\
\hline $\begin{array}{c}\text { methyl } \\
\text { 2-nonynoate }\end{array}$ & $\mathrm{C}_{10} \mathrm{H}_{16} \mathrm{O}_{2}$ & $111-80-8$ & 800 & 1292 & 1311 & - & $x$ & - & $\mathrm{x}$ & $\begin{array}{l}\text { floral, green, violet leaf, } \\
\text { melon and cucumber }\end{array}$ & $\begin{array}{l}\text { green melon, cucumber, violet } \\
\text { tropical fruity }\end{array}$ \\
\hline 2-dodecanol & $\mathrm{C}_{12} \mathrm{H}_{26} \mathrm{O}$ & $10203-28-8$ & 839 & 1312 & - & $\mathrm{x}$ & $x$ & - & - & - & - \\
\hline isocarveol & $\mathrm{C}_{10} \mathrm{H}_{16} \mathrm{O}$ & $536-59-4$ & 879 & 1313 & - & $\mathrm{x}$ & $\mathrm{x}$ & - & $\mathrm{x}$ & $\begin{array}{l}\text { green, linalool, terpineol } \\
\text { and fatty }\end{array}$ & $\begin{array}{l}\text { sweet, woody, aromatic spicy } \\
\text { cardamom and green cumin } \\
\text { like with dried orange peel } \\
\text { and green waxy floral } \\
\text { nuances }\end{array}$ \\
\hline 4-vinylguaiacol & $\mathrm{C}_{9} \mathrm{H}_{10} \mathrm{O}_{2}$ & 7786-61-0 & 902 & 1323 & - & $\mathrm{x}$ & - & $\mathrm{x}$ & - & $\begin{array}{l}\text { dry, woody, fresh amber } \\
\text { cedar and roasted peanut }\end{array}$ & smoky bacon \\
\hline $\begin{array}{l}\text { (E)-methyl } \\
\text { geranate }\end{array}$ & $\mathrm{C}_{11} \mathrm{H}_{18} \mathrm{O}_{2}$ & 1189-09-9 & 918 & 1329 & - & $\mathrm{x}$ & $\mathrm{x}$ & $\mathrm{x}$ & $\mathrm{x}$ & waxy, green, fruity flower & - \\
\hline myrtanyl acetate & $\mathrm{C}_{12} \mathrm{H}_{20} \mathrm{O}_{2}$ & 29021-36-1 & 808 & 1351 & - & $\mathrm{x}$ & - & - & - & - & - \\
\hline $\begin{array}{l}\text { citronellyl } \\
\text { acetate }\end{array}$ & $\mathrm{C}_{12} \mathrm{H}_{22} \mathrm{O}_{2}$ & $150-84-5$ & 873 & 1353 & - & $\mathrm{x}$ & $\mathrm{x}$ & $\mathrm{x}$ & $\mathrm{x}$ & $\begin{array}{l}\text { floral green rose, fruity, } \\
\text { citrus, woody and tropical } \\
\text { fruit }\end{array}$ & $\begin{array}{l}\text { floral, waxy, aldehydic, with } \\
\text { green fruity nuances. fruity } \\
\text { pear and apple like }\end{array}$ \\
\hline$\alpha$-ylangene & $\mathrm{C}_{15} \mathrm{H}_{24}$ & $14912-44-8$ & 812 & 1371 & 1372 & $x$ & - & - & - & - & - \\
\hline$\gamma$-nonanolactone & $\mathrm{C}_{9} \mathrm{H}_{16} \mathrm{O}_{2}$ & $104-61-0$ & 818 & 1374 & 1363 & - & $\mathrm{x}$ & - & - & $\begin{array}{l}\text { coconut, creamy, waxy } \\
\text { sweet, buttery oily }\end{array}$ & $\begin{array}{l}\text { coconut, creamy, waxy with } \\
\text { fatty milky notes }\end{array}$ \\
\hline$\alpha$-copaene & $\mathrm{C}_{15} \mathrm{H}_{24}$ & $3856-25-5$ & 861 & 1377 & - & $\mathrm{x}$ & - & - & - & woody & - \\
\hline
\end{tabular}


Table 1. Cont

\begin{tabular}{|c|c|c|c|c|c|c|c|c|c|c|c|}
\hline \multirow[t]{2}{*}{ Compound } & \multirow[t]{2}{*}{ Formula } & \multirow[t]{2}{*}{ CAS } & \multirow[t]{2}{*}{ Match } & \multicolumn{2}{|c|}{ LTPRI } & \multicolumn{2}{|c|}{ Detection } & \multicolumn{2}{|c|}{$\begin{array}{l}\text { Template } \\
\text { Matching }\end{array}$} & \multirow[t]{2}{*}{ Odor } & \multirow[t]{2}{*}{ Flavor } \\
\hline & & & & Exp & NIST & BR & ENG & BR & ENG & & \\
\hline $\begin{array}{c}\text { ethyl } \\
\text { trans-4-decenoate }\end{array}$ & $\mathrm{C}_{12} \mathrm{H}_{22} \mathrm{O}_{2}$ & 76649-16-6 & 878 & 1381 & - & $\mathrm{x}$ & $\mathrm{x}$ & $\mathrm{x}$ & - & $\begin{array}{l}\text { green, fruity, waxy and } \\
\text { cognac }\end{array}$ & $\begin{array}{l}\text { fatty, waxy, green, pineapple } \\
\text { and pear nuances }\end{array}$ \\
\hline geranyl acetate & $\mathrm{C}_{12} \mathrm{H}_{20} \mathrm{O}_{2}$ & $105-87-3$ & 836 & 1381 & 1382 & $\mathrm{x}$ & $\mathrm{x}$ & $\mathrm{x}$ & $\mathrm{x}$ & $\begin{array}{l}\text { floral rose lavender, green } \\
\text { and waxy }\end{array}$ & $\begin{array}{l}\text { waxy, green, floral, oily and } \\
\text { soapy with citrus and winey, } \\
\text { rum nuances }\end{array}$ \\
\hline ethyl 9-decenoate & $\mathrm{C}_{12} \mathrm{H}_{22} \mathrm{O}_{2}$ & 67233-91-4 & 858 & 1389 & 1387 & $\mathrm{x}$ & $\mathrm{x}$ & - & $\mathrm{x}$ & fruity, fatty & - \\
\hline ethyl decanoate & $\mathrm{C}_{12} \mathrm{H}_{24} \mathrm{O}_{2}$ & $110-38-3$ & 910 & 1396 & 1396 & $\mathrm{x}$ & - & $\mathrm{x}$ & - & $\begin{array}{l}\text { sweet, waxy, fruity, apple } \\
\text { grape and oily brandy }\end{array}$ & waxy, fruity, sweet apple \\
\hline isopulegol acetate & $\mathrm{C}_{12} \mathrm{H}_{20} \mathrm{O}_{2}$ & $57576-09-7$ & 801 & 1420 & - & - & $\mathrm{x}$ & - & - & $\begin{array}{l}\text { woody, sweet peppermint, } \\
\text { tropical }\end{array}$ & $\begin{array}{l}\text { woody, berry green and } \\
\text { camphoreous with a fruity } \\
\text { nuance }\end{array}$ \\
\hline $\begin{array}{l}\text { bicyclo[4.1.0]heptane, } \\
\text { 7-(1-methylethylidene) }\end{array}$ & $\mathrm{C}_{10} \mathrm{H}_{16}$ & $53282-47-6$ & 831 & 1420 & - & $\mathrm{x}$ & - & - & - & - & - \\
\hline isocaryophyllene & $\mathrm{C}_{15} \mathrm{H}_{24}$ & $118-65-0$ & 890 & 1423 & 1406 & - & $\mathrm{x}$ & - & - & woody, spicy & \\
\hline caryophyllene & $\mathrm{C}_{15} \mathrm{H}_{24}$ & $87-44-5$ & 939 & 1423 & 1419 & $\mathrm{x}$ & $\mathrm{x}$ & $\mathrm{x}$ & - & $\begin{array}{l}\text { sweet, woody, spice clove } \\
\text { dry }\end{array}$ & $\begin{array}{l}\text { spicy, clove, woody, nut skin } \\
\text { and powdery peppery }\end{array}$ \\
\hline $\begin{array}{l}\text { p-mentha-1(7),8(10)- } \\
\text { dien-9-ol }\end{array}$ & $\mathrm{C}_{10} \mathrm{H}_{16} \mathrm{O}$ & 29548-13-8 & 845 & 1440 & - & $\mathrm{x}$ & - & - & - & - & - \\
\hline perillyl acetate & $\mathrm{C}_{12} \mathrm{H}_{18} \mathrm{O}_{2}$ & 15111-96-3 & 863 & 1440 & 1436 & $\mathrm{x}$ & $\mathrm{x}$ & - & $\mathrm{x}$ & $\begin{array}{l}\text { fruity, woody and } \\
\text { raspberry }\end{array}$ & ionone raspberry \\
\hline isoamyl octanoate & $\mathrm{C}_{13} \mathrm{H}_{26} \mathrm{O}_{2}$ & 2035-99-6 & 812 & 1448 & 1446 & $\mathrm{x}$ & - & $\mathrm{x}$ & - & $\begin{array}{l}\text { sweet, oily, fruity, green } \\
\text { soapy, pineapple and } \\
\text { coconut }\end{array}$ & $\begin{array}{l}\text { sweet, fruity, waxy, pineapple, } \\
\text { fruity and green with coconut } \\
\text { and cognac nuances }\end{array}$ \\
\hline$\alpha$-humulene & $\mathrm{C}_{15} \mathrm{H}_{24}$ & $6753-98-6$ & 915 & 1460 & - & $\mathrm{x}$ & $\mathrm{x}$ & $\mathrm{x}$ & - & woody & - \\
\hline$\gamma$-muurolene & $\mathrm{C}_{15} \mathrm{H}_{24}$ & $30021-74-0$ & 887 & 1478 & - & $\mathrm{x}$ & - & $\mathrm{x}$ & - & herbal, woody and spice & - \\
\hline farnesyl butanoate & $\mathrm{C}_{19} \mathrm{H}_{32} \mathrm{O}_{2}$ & $51532-27-5$ & 811 & 1485 & - & $\mathrm{x}$ & - & $\mathrm{x}$ & - & - & - \\
\hline aromadendrene & $\mathrm{C}_{15} \mathrm{H}_{24}$ & 72747-25-2 & 861 & 1496 & - & $\mathrm{x}$ & - & $\mathrm{x}$ & - & woody & - \\
\hline
\end{tabular}


Table 1. Cont.

\begin{tabular}{|c|c|c|c|c|c|c|c|c|c|c|c|}
\hline \multirow[t]{2}{*}{ Compound } & \multirow[t]{2}{*}{ Formula } & \multirow[t]{2}{*}{ CAS } & \multirow[t]{2}{*}{ Match } & \multicolumn{2}{|c|}{ LTPRI } & \multicolumn{2}{|c|}{ Detection } & \multicolumn{2}{|c|}{$\begin{array}{l}\text { Template } \\
\text { Matching }\end{array}$} & \multirow[t]{2}{*}{ Odor } & \multirow[t]{2}{*}{ Flavor } \\
\hline & & & & Exp & NIST & BR & ENG & BR & ENG & & \\
\hline $\begin{array}{l}\text { guaia-1(10), } \\
\text { 11-diene }\end{array}$ & $\mathrm{C}_{15} \mathrm{H}_{24}$ & - & 875 & 1501 & 1509 & $\mathrm{x}$ & - & $\mathrm{x}$ & - & - & - \\
\hline $\begin{array}{c}\text { neryl } \\
\text { isobutanoate }\end{array}$ & $\mathrm{C}_{14} \mathrm{H}_{24} \mathrm{O}_{2}$ & $2345-24-6$ & 840 & 1509 & 1487 & $\mathrm{x}$ & - & - & - & $\begin{array}{l}\text { sweet, fresh, fruity, } \\
\text { raspberry, strawberry, } \\
\text { green }\end{array}$ & $\begin{array}{l}\text { juicy and fruity, green, sweet, } \\
\text { melon and waxy }\end{array}$ \\
\hline neryl hexanoate & $\mathrm{C}_{16} \mathrm{H}_{28} \mathrm{O}_{2}$ & 68310-59-8 & 865 & 1510 & - & $\mathrm{x}$ & - & $\mathrm{x}$ & - & - & - \\
\hline$\gamma$-amorphene & $\mathrm{C}_{15} \mathrm{H}_{24}$ & 6980-46-7 & 903 & 1517 & 1496 & $\mathrm{x}$ & - & - & - & - & - \\
\hline delta-amorphene & $\mathrm{C}_{15} \mathrm{H}_{24}$ & 16729-01-4 & 904 & 1522 & - & $\mathrm{x}$ & - & $\mathrm{x}$ & - & - & - \\
\hline cis-calamenene & $\mathrm{C}_{15} \mathrm{H}_{22}$ & 72937-55-4 & 869 & 1527 & 1531 & $\mathrm{x}$ & - & $\mathrm{x}$ & - & - & - \\
\hline cadinadiene- 1,4 & $\mathrm{C}_{15} \mathrm{H}_{24}$ & 16728-99-7 & 823 & 1537 & 1533 & $\mathrm{x}$ & - & - & - & - & - \\
\hline$\alpha$-muurolene & $\mathrm{C}_{15} \mathrm{H}_{24}$ & 31983-22-9 & 836 & 1541 & - & $\mathrm{x}$ & - & - & - & - & - \\
\hline cis-7-hexadecene & $\mathrm{C}_{16} \mathrm{H}_{32}$ & 35507-09-6 & 884 & 1590 & 1566 & $\mathrm{x}$ & - & - & - & - & - \\
\hline $\begin{array}{c}\text { caryophyllene } \\
\text { oxide }\end{array}$ & $\mathrm{C}_{15} \mathrm{H}_{24} \mathrm{O}$ & 1139-30-6 & 914 & 1590 & 1581 & $\mathrm{x}$ & $\mathrm{x}$ & $\mathrm{x}$ & - & $\begin{array}{l}\text { sweet, fresh, dry, woody } \\
\text { and spicy }\end{array}$ & $\begin{array}{l}\text { dry, woody, cedar old, carrot, } \\
\text { ambrette amber }\end{array}$ \\
\hline $\begin{array}{c}\text { Ethyl } \\
\text { dodecanoate }\end{array}$ & $\mathrm{C}_{14} \mathrm{H}_{28} \mathrm{O}_{2}$ & $106-33-2$ & 862 & 1594 & 1595 & $\mathrm{x}$ & - & $\mathrm{x}$ & - & $\begin{array}{l}\text { sweet, waxy, floral, soapy } \\
\text { clean }\end{array}$ & $\begin{array}{l}\text { waxy, soapy and floral with a } \\
\text { creamy, dairy and fruity } \\
\text { nuance }\end{array}$ \\
\hline bisaboladien-4-ol & $\mathrm{C}_{15} \mathrm{H}_{26} \mathrm{O}$ & - & 800 & 1608 & - & $\mathrm{x}$ & $\mathrm{x}$ & - & $\mathrm{x}$ & - & - \\
\hline humulol & $\mathrm{C}_{15} \mathrm{H}_{26} \mathrm{O}$ & 28446-26-6 & 862 & 1613 & - & - & $\mathrm{x}$ & - & & - & - \\
\hline $\begin{array}{l}\text { humulene-1,2- } \\
\text { epoxide }\end{array}$ & $\mathrm{C}_{15} \mathrm{H}_{24} \mathrm{O}$ & 19888-34-7 & 914 & 1619 & - & $\mathrm{x}$ & $\mathrm{x}$ & - & $\mathrm{x}$ & - & - \\
\hline epicubenol & $\mathrm{C}_{15} \mathrm{H}_{26} \mathrm{O}$ & 19912-67-5 & 870 & 1624 & 1627 & $\mathrm{x}$ & $\mathrm{x}$ & - & - & - & - \\
\hline cubenol & $\mathrm{C}_{15} \mathrm{H}_{26} \mathrm{O}$ & 21284-22-0 & 878 & 1636 & 1642 & $\mathrm{x}$ & $\mathrm{x}$ & - & - & spicy, herbal green tea & - \\
\hline $\begin{array}{l}\text { alloaromadendrene } \\
\text { oxide }\end{array}$ & $\mathrm{C}_{15} \mathrm{H}_{24} \mathrm{O}$ & - & 833 & 1645 & - & $\mathrm{x}$ & $\mathrm{x}$ & - & $\mathrm{x}$ & - & - \\
\hline$\tau$-cadinol & $\mathrm{C}_{15} \mathrm{H}_{26} \mathrm{O}$ & - & 902 & 1650 & 1640 & $\mathrm{x}$ & $\mathrm{x}$ & - & - & - & - \\
\hline intermedeol & $\mathrm{C}_{15} \mathrm{H}_{26} \mathrm{O}$ & $6168-59-8$ & 800 & 1667 & 1667 & $\mathrm{x}$ & $\mathrm{x}$ & $\mathrm{x}$ & - & - & - \\
\hline elemol acetate & $\mathrm{C}_{17} \mathrm{H}_{28} \mathrm{O}_{2}$ & - & 800 & 1681 & - & $\mathrm{x}$ & $\mathrm{x}$ & - & - & - & - \\
\hline $\begin{array}{l}4(15), 5,10(14)- \\
\text { germacratrien-1-ol }\end{array}$ & $\mathrm{C}_{15} \mathrm{H}_{24} \mathrm{O}$ & 81968-62-9 & 800 & 1694 & 1695 & $\mathrm{x}$ & $\mathrm{x}$ & - & $x$ & - & - \\
\hline 10-heneicosene & $\mathrm{C}_{10} \mathrm{H}_{16} \mathrm{O}$ & 95008-11-0 & 854 & 1792 & - & & $\mathrm{x}$ & - & - & - & - \\
\hline
\end{tabular}




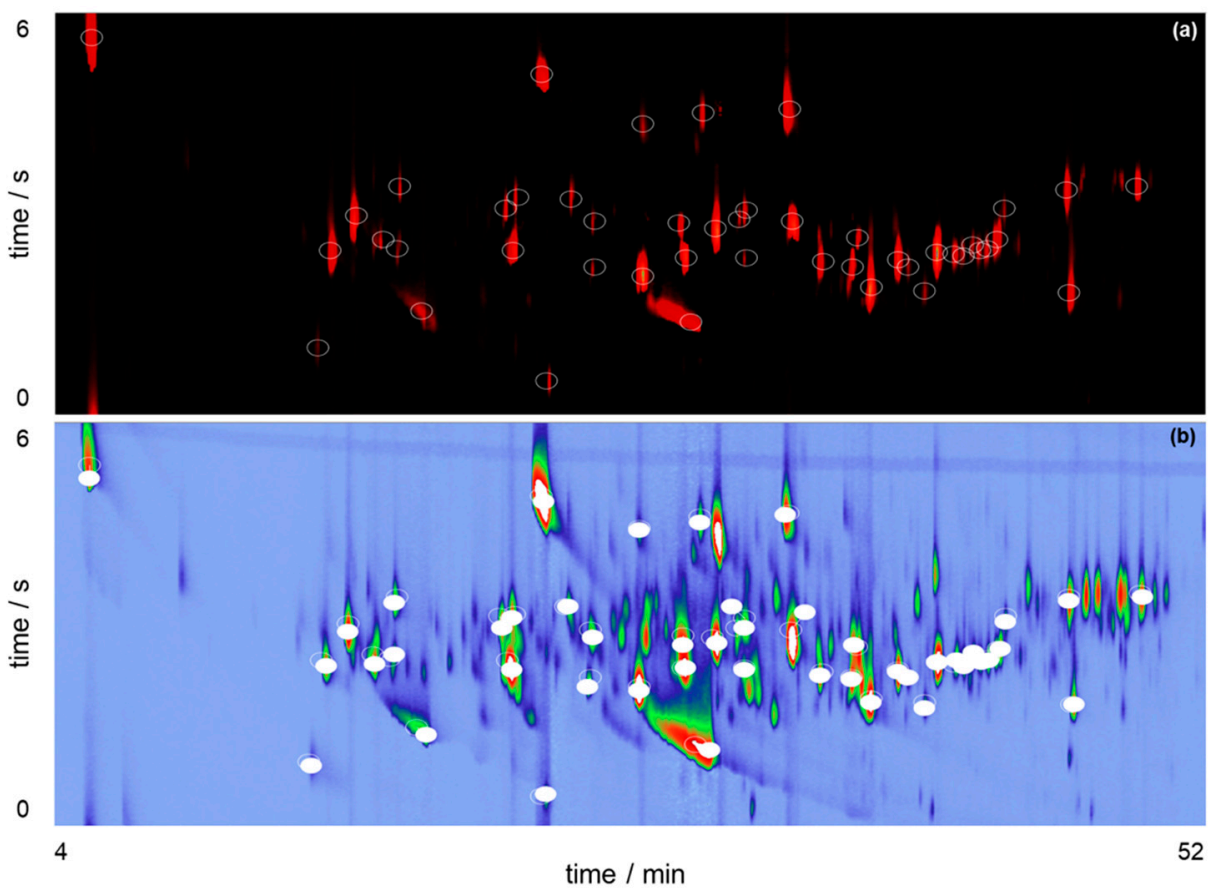

Figure 5. (a) Peak template creation using the loadings vector and the reconstructed chromatogram; (b) Process of template matching using GC Image highlighting potential unique compounds in the GC $\times$ GC-QMS total ion chromatogram of the BR beer sample.

Template matching revealed 46 compounds that were exclusively in one sample or in both, but with distinguished intensities. Table 1 summarizes all the compounds identified by the approach described herein.

According to the data of Table 1, ENG brewing enabled retention/formation of higher alcohols and monoterpene alcohols. Template matching identified compounds that were present in higher quantities in the ENG sample, including alcohols and esters. These chemical classes are known to enhance fruity notes to the sample; examples include cis-geraniol; trans-geraniol and 2-phenylethyl acetate.

Furthermore, the chemometric approach highlighted that the Brazilian Ale 02 yeast supported the formation and/or retention of terpenic compounds in the beer. The terpenoids caryophyllene oxide, beta-pinene, and caryophyllene contribute to enhance spicy aromas and flavors in the beer, corroborating the information presented in the datasheet of the Brazilian Ale 02 yeast [34]. Classification of terpenic compounds depends on the number of repetitions of the isoprene unit $\left(\mathrm{C}_{5} \mathrm{H}_{8}\right)$, being monoterpenic compounds (two isoprene units), sequiterpenic compounds (three isoprene units) and so on [35]. Their presence in a beer comes mostly from the hops added during brewing, which act as preservative and impart the bitterness characteristic of beers [23]. A minor source to these chemical compounds may be the yeast's metabolism. King et al. [36] demonstrated that ale and lager yeasts are capable of biotransforming the monoterpene alcohols trans-geraniol and linalool into other monoterpene alcohols or esters.

Finally, template matching provided conditions to the identification of the bioaromatization properties introduced in the aroma profile of the beer by the unique Brazilian yeast. The approach enabled the identification of seven compounds that were found exclusively in the BR samples, chemical classes found include esters (ethyl phenylacetate; ethyl decanoate; isoamyl octanoate; ethyl dodecanoate), terpenes ( $\gamma$-muurolene; aromadendrene) and a phenolic compound (4-vinylguaiacol). Unfortunately, due to synergistic and antagonistic effects it is difficult to know what will be the effect that different levels of higher alcohols and esters will have on the overall profile of the beer [27]. Therefore, the data analyzed provided general answers about the aroma that compounds can impart to 
the beer. These findings highlight the necessity of allying a sensory panel of specialists to taste beer samples and to elucidate the influence of such compounds to the aroma of beers.

Furthermore, there is a threshold in which a compound with a concentration lower than that will not be perceived, but also due to synergistic effects the presence of different esters can affect beer flavor even if they are well below their individual threshold concentrations [27]. This is valid for both desired and undesired molecules. Examples of undesired compounds (off-flavors) and their individual sensory threshold in beers include the esters isoamyl acetate $\left(1400 \mathrm{ng} \mathrm{mL}^{-1}\right)$; ethyl acetate $\left(15,000 \mathrm{ng} \mathrm{mL}^{-1}\right)$; ethyl hexanoate (200 $\left.\mathrm{ng} \mathrm{mL}^{-1}\right)$ and 2,3-butanedione $\left(40 \mathrm{ng} \mathrm{mL}^{-1}\right)$ [37]. Ethyl hexanoate and isoamyl acetate were both detected in BR and ENG, which highlights how difficult it is to produce beers without off-flavors.

\section{Conclusions}

The steady increase in beer consumption over the past decades demonstrates the notorious importance that the beverage possesses in a global scenario. Therefore, the search for better quality beers is fundamental nowadays. In this study, we evaluated a bottom-up approach to reveal the novel contributions that the Brazilian Ale 02 yeast could impart in the VOC profile of a beer. The protocol adopted succeeded in comparing both beer samples based on yeast strain, highlighting 46 compounds as relevant for sample classification. Furthermore, multiway principal components analysis discarded unrelated information from the GC $\times$ GC-MS chromatograms, which enabled simple and efficient data mining, even by non-expert users. It was possible to accurately identify seven key markers spotted in the VOC profile of the BR sample due to the use of the unique Brazilian yeast during brewing.

These outcomes highlighted the importance of combining high peak capacity techniques, as comprehensive two-dimensional gas chromatography, with appropriate data processing techniques such as MPCA. Finally, we expect to continue the research through the analyses of more samples and the alignment of a sensory panel of specialists to obtain comprehensive aroma-related information among beers.

Author Contributions: D.S.O. brewed the beer samples. A.C.P., D.S.O. and L.W.H. conceived and planned the experiments. A.C.P. performed the experiments, collected and processed all the data. A.C.P. and L.W.H. wrote the paper with input from all authors.

Funding: This research was funded by National Council for Scientific and Technological Development (CNPq 400182/2016-5), São Paulo Research Foundation (17/25490-1), and Unicamp (FAEPEX 519.292). Andre Cunha Paiva thanks the Coordination for the Improvement of Higher Education Personnel (CAPES 88882.329162/2019-01) for research fellowships.

Acknowledgments: We are indebted to Danilo Pierone and Felipe Lugão (Nova Analítica Imp. Exp.) for generously providing Thermo Scientific instruments.

Conflicts of Interest: The authors declare no conflicts of interest.

\section{References}

1. KIRIN HOLDINGS. Available online: https://www.kirinholdings.co.jp/english/news/2018/1220_01.html (accessed on 2 April 2019).

2. Vasconcelos, Y. Inovações cervejeiras. Pesqui. Fapesp 2017, 251, 18-25.

3. da Silva, G.A.; Augusto, F.; Poppi, R.J. Exploratory analysis of the volatile profile of beers by HS-SPME-GC. Food Chem. 2008, 111, 1057-1063.

4. Martins, C.; Brandão, T.; Almeida, A.; Rocha, S.M. Insights on beer volatile profile: Optimization of solid-phase microextraction procedure taking advantage of the comprehensive two-dimensional gas chromatography structured separation. J. Sep. Sci. 2015, 38, 2140-2148. [PubMed]

5. Venturini Filho, W.G. Bebidas alcoólicas: Ciência e Tecnologia, 2nd ed.; Edgard Blücher Ltda.: Sao Paulo, Brazil, 2016.

6. Vanderhaegen, B.; Neven, H.; Coghe, S.; Verstrepen, K.J.; Verachtert, H.; Derdelinckx, G. Evolution of Chemical and Sensory Properties during Aging of Top-Fermented Beer. J. Agric. Food Chem. 2003, 51, 6782-6790. [PubMed] 
7. Saison, D.; De Schutter, D.P.; Delvaux, F.; Delvaux, F.R. Optimisation of a complete method for the analysis of volatiles involved in the flavour stability of beer by solid-phase microextraction in combination with gas chromatography and mass spectrometry. J. Chromatogr. A 2008, 1190, 342-349. [PubMed]

8. Rodrigues, J.A.; Barros, A.S.; Carvalho, B.; Brandão, T.; Gil, A.M.; Ferreira, A.C.S. Evaluation of beer deterioration by gas chromatography-mass spectrometry/multivariate analysis: A rapid tool for assessing beer composition. J. Chromatogr. A 2011, 1218, 990-996. [PubMed]

9. Pizarro, C.; Pérez-del-Notario, N.; González-Sáiz, J.M. Optimisation of a simple and reliable method based on headspace solid-phase microextraction for the determination of volatile phenols in beer. J. Chromatogr. A 2010, 1217, 6013-6021.

10. Basso, R.F.; Alcarde, A.R.; Portugal, C.B. Could non-Saccharomyces yeasts contribute on innovative brewing fermentations? Food Res. Int. 2016, 86, 112-120.

11. Arthur, C.; Pawliszyn, J. Solid Phase Microextraction with Thermal Desorption Using Fused Silica Optical Fibers. Anal. Chem. 1990, 62, 2145-2148.

12. Jeleń, H.H.; Majcher, M.; Dziadas, M. Microextraction techniques in the analysis of food flavor compounds: A review. Anal. Chim. Acta 2012, 738, 13-26.

13. Lord, H.; Pawliszyn, J. Evolution of solid-phase microextraction technology. J. Chromatogr. A 2000, 885, 153-193.

14. Kataoka, H.; Lord, H.L.; Pawliszyn, J. Applications of solid-phase microextraction in food analysis. J. Chromatogr. A 2000, 880, 35-62. [PubMed]

15. Sterckx, F.L.; Saison, D.; Delvaux, F.R. Determination of volatile monophenols in beer using acetylation and headspace solid-phase microextraction in combination with gas chromatography and mass spectrometry. Anal. Chim. Acta 2010, 676, 53-59. [PubMed]

16. Kobayashi, M.; Shimizu, H.; Shioya, S. Beer Volatile Compounds and Their Application to Low-Malt Beer Fermentation. J. Biosci. Bioeng. 2008, 106, 317-323. [PubMed]

17. Riu-Aumatell, M.; Miró, P.; Serra-Cayuela, A.; Buxaderas, S.; López-Tamames, E. Assessment of the aroma profiles of low-alcohol beers using HS-SPME-GC-MS. Food Res. Int. 2014, 57, 196-202.

18. Saison, D.; De Schutter, D.P.; Delvaux, F.; Delvaux, F.R. Determination of carbonyl compounds in beer by derivatisation and headspace solid-phase microextraction in combination with gas chromatography and mass spectrometry. J. Chromatogr. A 2009, 1216, 5061-5068. [PubMed]

19. Tian, J. Determination of several flavours in beer with headspace sampling-gas chromatography. Food Chem. 2010, 123, 1318-1321.

20. Leça, J.M.; Pereira, A.C.; Vieira, A.C.; Reis, M.S.; Marques, J.C. Optimal design of experiments applied to headspace solid phase microextraction for the quanti fi cation of vicinal diketones in beer through gas chromatography-mass spectrometric detection. Anal. Chim. Acta 2015, 887, 101-110.

21. Cajka, T.; Riddellova, K.; Tomaniova, M.; Hajslova, J. Recognition of beer brand based on multivariate analysis of volatile fingerprint. J. Chromatogr. A 2010, 1217, 4195-4203.

22. Griffith, J.F.; Winniford, W.L.; Sun, K.; Edam, R.; Luong, J.C. A reversed-flow differential flow modulator for comprehensive two-dimensional gas chromatography. J. Chromatogr. A 2012, 1226, 116-123.

23. Martins, C.; Brandão, T.; Almeida, A.; Rocha, S.M. Unveiling the lager beer volatile terpenic compounds. Food Res. Int. 2018, 114, 199-207. [PubMed]

24. Callao, M.P.; Ruisánchez, I. An overview of multivariate qualitative methods for food fraud detection. Food Control 2018, 86, 283-293.

25. Escandar, G.M.; Olivieri, A.C.; Faber, N.M.; Goicoechea, H.C.; Muñoz de la Peña, A.; Poppi, R.J. Second- and third-order multivariate calibration: Data, algorithms and applications. TrAC Trends Anal. Chem. 2007, 26, 752-765.

26. Olivieri, A.C. Analytical Advantages of Multivariate Data Processing. One, Two, Three, Infinity? Anal. Chem. 2008, 80, 5713-5720. [PubMed]

27. Meilgaard, M.C. Flavor chemistry in beer: Part I: Flavor interaction between principal volatiles. Master Brew. Assoc. Am. Tech. Q. 1975, 12, 107-117.

28. Verstrepen, K.J.; Derdelinckx, G.; Dufour, J.-P.; Winderickx, J.; Thevelein, J.M.; Pretorius, I.S.; Delvaux, F.R. Flavor-Active Esters: Adding Fruitiness to Beer. J. Biosci. Bioeng. 2003, 96, 110-118. 
29. Zhu, M.; Cui, Y. Determination of 4-vinylgaiacol and 4-vinylphenol in top-fermented wheat beers by isocratic high performance liquid chromatography with ultraviolet detector. Braz. Arch. Biol. Technol. 2013, 56, 1018-1023.

30. Kishimoto, T.; Noba, S.; Yako, N.; Kobayashi, M.; Watanabe, T. Simulation of Pilsner-type beer aroma using 76 odor-active compounds. J. Biosci. Bioeng. 2018, 126, 330-338.

31. Snow, N.H.; Sinex, J.; Danser, M. Multiple Dimensions of Separations: SPME with GC $\times$ GC and GC ×GC-TOF-MS. Lc Gc Eur. 2010, 23, 260-267.

32. Crucello, J.; Miron, L.F.O.; Ferreira, V.H.C.; Nan, H.; Marques, M.O.M.; Ritschel, P.S.; Zanus, M.C.; Anderson, J.L.; Poppi, R.J.; Hantao, L.W. Characterization of the aroma profile of novel Brazilian wines by solid-phase microextraction using polymeric ionic liquid sorbent coatings. Anal. Bioanal. Chem. 2018, 410, $4749-4762$.

33. The Good Scents Company. Available online: http://www.thegoodscentscompany.com/ (accessed on 6 August 2019).

34. Yeastlab Biotecnologia. Available online: http://yeastlab.com.br/Files/YLB6001\%20-\%2001.pdf (accessed on 2 April 2019).

35. Kumari, S.; Priya, P.; Misra, G.; Yadav, G. Structural and biochemical perspectives in plant isoprenoid biosynthesis. Phytochem. Rev. 2013, 12, 255-291.

36. King, A.J.; Dickinson, J.R. Biotransformation of hop aroma terpenoids by ale and lager yeasts. FEMS Yeast Res. 2003, 3, 53-62. [PubMed]

37. Silva, G.C.; Silva, A.A.S.; Silva, L.S.N.; Godoy, R.L.D.O.; Nogueira, L.C.; Quitério, S.L.; Raices, R.S.L. Method development by GC-ECD and HS-SPME-GC-MS for beer volatile analysis. Food Chem. 2015, 167, 71-77. [PubMed]

(C) 2019 by the authors. Licensee MDPI, Basel, Switzerland. This article is an open access article distributed under the terms and conditions of the Creative Commons Attribution (CC BY) license (http://creativecommons.org/licenses/by/4.0/). 